Bryn Mawr College

Scholarship, Research, and Creative Work at Bryn Mawr College

Classical and Near Eastern Archaeology Faculty

Research and Scholarship

Classical and Near Eastern Archaeology

1967

\title{
The Lady from the Sea: A Greek Bronze in Turkey
}

Brunilde S. Ridgway

Bryn Mawr College, bridgway@brynmawr.edu

Let us know how access to this document benefits you.

Follow this and additional works at: http://repository.brynmawr.edu/arch_pubs

Part of the Classical Archaeology and Art History Commons, and the History of Art, Architecture, and Archaeology Commons

\section{Custom Citation}

Ridgway, Brunilde S. 1967. The Lady from the Sea: A Greek Bronze in Turkey. American Journal of Archaeology 71:329-334.

This paper is posted at Scholarship, Research, and Creative Work at Bryn Mawr College. http://repository.brynmawr.edu/arch_pubs/52

For more information, please contact repository@brynmawr.edu. 


\title{
The Lady from the Sea: A Greek Bronze in Turkey
}

\author{
BRUNILDE SISMONDO RIDGWAY
}

PLATES 97-100

The traveling exhibit "Art Treasures of Turkey" circulated by the Smithsonian Institution during I966-I968 has brought to the United States, among other priceless objects, a little known but most important piece of bronze statuary: the fragmentary torso of a veiled woman (pl. 97, fig. I). I had the opportunity of examining it while the exhibit was in Philadelphia at the University Museum, ${ }^{1}$ and I now owe the permission to publish my observations to the great kindness of Hakki Gültekin, director of the Izmir Museum.

The statue was found on August 9, 1953, by some fishermen operating along the coast of Asia Minor near Arap Adas1, not too far from the Knidian peninsula. ${ }^{2}$ Brought to the village of Bitez, near Bodrum, the statue lay on the beach until it attracted the attention of G. E. Bean, who had it removed to the Izmir Museum where it now permanently resides (inv. no. 3544).

The piece is virtually unpublished. Prof. Bean, soon after discovering it, presented a brief and exciting account of the find in the Illustrated London News; $;^{3}$ the accompanying photographs show the bronze still heavily encrusted, before cleaning. I know of only two other mentions of this work,

\footnotetext{
I I am greatly indebted to Prof. Rodney S. Young and to Mr. David Crownover for allowing the statue to be removed from its setting to be photographed. I am equally grateful to Messrs. Kamil Su and Necati Dolunay, who accompanied the exhibit as representatives of the Turkish Government, generously granted permission to photograph the piece under their care, and gave unstintingly of their time. My final thanks go to Mr. Karl Dimler, photographer at Bryn Mawr College, for the detailed pictures of the bronze. I owe the photograph, pl. 97, fig. I, to the courtesy of the University Museum. Mrs. Miriam Ervin has greatly improved my text and has contributed many observations based on the reading of the photographs. The Turkish Exhibit was in Philadelphia from October 16 to November 27, 1966. The content of this article was presented as a paper at the annual meetings of the College Art Association of America in Cleveland, Ohio, on January 27,1967 .

2 According to G. Bass (Archaeology under Water, Ancient Peoples and Places Series, vol. 48 [New York 1966] 82) the bronze was "pulled up from perhaps 300 feet of water in sponge-dragger Ahmet Erbil's net." For the location see the map in $I L N$ Nov. 7, 1953, 748 fig. 2. Two possible positions are there indicated, but Prof. Bass informs me that Arap Adasi, directly north of the northernmost tip of Rhodes, is the correct finding spot. The University Museum has already made
}

besides the entry in the catalogue of the traveling exhibit. $^{5}$

Bean considered the statue a representation of Demeter, and the name has lingered. Under the understandable influence of the find spot, the British scholar established a parallel with the seated marble Demeter from Knidos now in the British Museum, ${ }^{6}$ and suggested, "at least provisionally," that the bronze was one of the many purchases made by Knidos around the middle of the fourth century B.c., when the transfer of the city to a new location within the peninsula demanded new statuary to adorn the new sanctuaries. ${ }^{7}$ Though admitting that no copies of the statue are extant and that there is a general dearth of similar pieces, particularly in bronze, Bean emphasized the stylistic and typological resemblances to the marble Demeter and assumed that the bronze also represented a seated figure. The Exhibition Catalogue repeated Bean's remarks and even suggested that the British Museum Demeter might have been made to replace this lost bronze. I have come to somewhat different conclusions, and therefore a description of the Izmir piece seems desirable.

one, unsuccessful, attempt to locate the wreck from which the statue came. Other attempts will follow.

3 Op.cit. (supra, n. 2) 747-749.

${ }^{4} \mathrm{G}$. Bass, op.cit. (supra, n. 2) with pl. 23, showing the piece after cleaning; and Enciclopedia Arte Antica, vol. 3, p. 65, s.v. Demetra.

${ }^{5}$ Art Treasures of Turkey, Smithsonian Institution publication No. 4663 (Washington 1966) 91, no. I30 with illustration. The section on Greek art was compiled by Rodney S. Young.

${ }^{6}$ R. Lullies and M. Hirmer, Greek Sculpture (2nd ed., New York 1960, henceforth cited as Lullies and Hirmer) pls. 224225. The Demeter is generally considered an original of the fourth century B.c., and B. Ashmole has specifically attributed it to Leochares ("Demeter of Cnidos," JHS 71 [195I] 13-28). R. Carpenter believes the statue dates from the Hellenistic period, ca. Ioo B.c. (Greek Sculpture [Chicago 1960] 173 and 213-214).

${ }^{7}$ Bean, at the time of writing for the $I L N$, was still uncertain between two possible locations, of which only the one nearer to Knidos would have satisfied the requirements of his conjecture. This supposition seems less tenable now that the finding spot has been localized with precision. Cf. supra, n. 2. 
The "Lady from the Sea" is actually only a head, with a large area missing over the forehead, and the front half of an armless torso. The back side is entirely lost. She is over lifesize, larger than the British Museum marble, ${ }^{8}$ a mature but youthful matron, with hair pulled back at the temples and almost totally hidden by drapery. By contrast, the Demeter of Knidos has long locks falling on either side of her neck down to the chest and a large portion of her hair is left uncovered by her wrap. The bronze lady is rather heavily dressed: a mantle with heavy folds crosses over her chest, fully covering the left breast but passing obliquely below the right. ${ }^{9}$ Under the himation a peplos is fastened over both shoulders, clearly visible on the right. Finally, at the neckline, the crinkly edge of a chiton emerges, now the only preserved indication of an undergarment which probably reappeared over the arms as buttoned sleeves, and around the ankles. This attire differs from that of the London Demeter, who is almost totally enveloped in her himation, with only a chiton underneath. The most basic difference lies in the head covering. While there is no question that the Knidian Demeter had her mantle pulled over her head, probably as a sign of mourning, the bronze lady clearly wears a separate veil, which descends lower over her hair and floats around her head with a most unusual, windswept effect. ${ }^{10}$

But the greatest point of discrepancy between the two statues is the pose. Contrary to general opinion, there is good evidence that the bronze figure is standing. The group of folds originating from the

\footnotetext{
8 The dimensions, as given by Bean, are: preserved height, $0.8 \mathrm{I} \mathrm{m}$; ; breadth of face, $0.17 \mathrm{~m}$.; distance from bridge of nose to chin, $0.13 \mathrm{~m}$. The breadth of face in the Demeter of Knidos is o.145 m. (as given in Ashmole, op.cit. supra n. 6, p. 19). For purposes of comparison, the distance from the bridge of the nose to the chin in a living model is $0.12 \mathrm{~m}$.

9 One may suppose that the mantle tightly enveloped the body, continuing under the armpits rather than extending over either arm; the arms themselves probably helped to keep the garment in place. For a somewhat comparable arrangement of a mantle encircling the waist cf. the Mantinea Base, G. M. A. Richter, Sculpture and Sculptors of the Greeks (New Haven 1950) fig. 68r, central Muse.

10 The identification of the drapery as veil is also supported by its casting technique, which will be discussed infra. For a typical example of a similar veil, though stylistically from a different period, see the so-called Hestia Giustiniani, $\mathrm{BrBr}$ 49I, and especially the back view, Richter, op.cit. (supra, n. 9) fig. 257. While a veil can be worn in several ways, according to extant statuary, a mantle either leaves the hair largely uncovered, as in the Demeter of Knidos, or it envelops the face like a hood, as in the so-called Aspasia, G. Lippold in W. Otto, Handbuch der Archäologie 3:r (Munich
}

left breast falls with a vertical course hardly in keeping with a seated position. Moreover, in its present state, the figure extends to slightly below the waist, and therefore, were it sitting, low enough to show the incurving outline of the lap necessitated by the seated pose. Since no such indication is apparent, we must infer that the bronze portrayed a standing matron.

The "Lady from the Sea" should therefore be described as a standing woman, heavily dressed in chiton, peplos and himation, with veiled head slightly inclined toward her left and presumably glancing at an object held in her left hand. It is also likely that her right arm extended forward and partly across the waist, since the folds over the right side are only roughly finished and obviously not meant to be seen. ${ }^{11}$ Her mantle, passing under both armpits, probably looped over her right arm and shoulder after encircling her back. Another important question is the identification. Who is the "Lady from the Sea"? Could she still be identified as Demeter, though typologically different from the Demeter of Knidos? Pose and costume are not distinctive enough to characterize the statue. A veiled head is not necessarily a sign of mourning, though it can be found on grave reliefs. ${ }^{12} \mathrm{~A}$ veil, or rather the lifting of the veil, often identifies a bride, and therefore the bride par excellence, Hera. ${ }^{13}$ Several divinities can wear a veil, for a variety of reasons: Ge, Leto, Amphitrite, Aphrodite and others; and very often heroines are represented with veiled head: Helen and Deianeira, for instance. ${ }^{14}$ The windblown effect

1950) pl. 32:2. However, it is admittedly difficult to distinguish between mantle and veil in many instances.

11 For a somewhat comparable pose, though not a similar attire, cf. the Aphrodite of Capua, Lippold, op.cit. (supra, n. 1o) pl. ror:3. The right arm should however be lower and the pose less torsional.

12 E.g. the Hegeso stele, Lullies and Hirmer pl. I87.

${ }^{13}$ Cf. e.g. a metope from temple $\mathrm{E}$ at Selinos, Lullies and Hirmer, pl. 127-an unusually long veil but quite distinct from the himation which the goddess wears.

${ }^{14}$ The above lists are drawn from a recent study, $\mathrm{H}$. Brandeburg, Studien zur Mitra (Münster 1966) 102-1 10, no. 9: "Die Mitra gennante Schleier in der Kleidung griechischer und römischer Frauen," where examples are listed for each personage, both in sculpture and vase painting. Demeter alone is not actually mentioned in connection with the veil, perhaps because a mantle drawn over the head is a clearer sign of mourning. Yet in the Homeric Hymn, at the news of her daughter's disappearance, Demeter "snatched a veil": see Pauly-Wissowa, $R E$, s.v. Kredemnon. So, at least for this one instance, Demeter cannot be excluded from the list of possible identifications. 
of the veil is more distinctive, but, to my knowledge, unparalleled. Remote comparisons can be established with figures of dancers, ${ }^{15}$ where however the rendering is justified by the motion, or with other personages pulling the head cover aside with the hand. ${ }^{16}$ But in the latter case only one side of the veil leaves the face, while in the Izmir bronze both sides seem to fluctuate. ${ }^{17}$ In summary, it seems best not to attach any specific connotation, divine, heroic or human, to the presence of the veil.

The rich wardrobe is also not significant and can be appropriate for either mortals or immortals. One would perhaps hesitate in associating it with Aphrodite, who is traditionally more scantily or provocatively dressed, but even this possibility cannot be excluded. ${ }^{18}$ The combination of chiton and peplos, often with a mantle, can be found on many grave reliefs ${ }^{19}$ and statues in the round, either divinities or human beings, both in the late Classical and Hellenistic periods. ${ }^{20}$ From Pergamon come several parallels, among which the most significant is perhaps the upper torso of a woman with chiton, peplos, himation drawn over the head, and diadem. ${ }^{21}$ It has been tentatively identified as a statue of Attalos II's mother, and dated within his reign or that of his successor, Attalos III, hence within the second century B.c.

Iconographically there exists, besides the seated version, a type of standing Demeter, perhaps best exemplified in a black marble statue in the Uffizi with arms and head in white stone. ${ }^{22}$ The goddess

${ }^{15}$ M. Bieber, Griechische Kleidung (Berlin 1928) pl. 32.

16 Cf., e.g., Selene, $E A$ 2745, the Corneto Aphrodite, $\mathrm{BrBr}$ 673:I, or some terracotta statuettes of Demeter from Eloro, Sicily, $A J A$ 70 (1966) pl. 87, fig. I4.

17 Of course, it cannot be excluded that this impression derives from the present state of preservation of the "Lady from the Sea," but that the rendering is intentional seems warranted by the technique employed to cast the veil, on which see infra.

18 Cf. e.g. Aphrodite Anadyomene in a Tarentine terracotta relief of Hellenistic date, where the goddess is represented on a chariot drawn over the waves by two Erotes, with her mantle billowing around her head. For a recent discussion of the type see A. Hundt and K. Peters, Greifswalder Antiken (Berlin I96I) III pl. 6I no. 484 .

19 See, e.g., H. Diepolder, Die attischen Grabreliefs (Berlin I93I) pl. 4I, stele of Ameinokleia.

20 See, e.g., M. Bieber, Entwicklungsgeschichte der griechischen Tracht (Berlin 1934), p. 34 and pls. 23 and 28 (classical time); p. 37 and pl. 34 (Hellenistic period); cf. also pl. 54:1 and 2 for the rendering in contrasting colors on living models.

21 F. Winter, Altertümer von Pergamon VII:I, Die Skulpturen (Berlin 1908), no. 87, pp. II2-II4, Beiblatt I2; for other comparisons see also no. 54, pp. 88-89, pl. 21 , and no. 63 , pp. 94-95, pl. 22b. is identifiable through the diadem decorated with ears of wheat, and it has been suggested that the use of contrasting colored marbles was meant to convey the image of a mourning Demeter. The Uffizi statue goes back to a mid-fourth century prototype, and does not compare too closely with the "Lady from the Sea": the attire is different, and the head turns in the opposite direction without the downward tilt so typical of the bronze. ${ }^{23}$

In consideration of the above it seems best, at the present state of our knowledge, to suspend judgment on the identification of the bronze. Demeter, though a possible candidate, is not necessarily the most obvious subject, and I am inclined to consider the "Lady from the Sea" an anonymous personage and a mortal rather than a divine figure. The large size and the material do not necessarily speak in favor of a cult purpose, ${ }^{24}$ and the statue could well have represented one of the many important women at the court of the great Hellenistic rulers. Further confirmation is perhaps provided by the date of the bronze. Unquestionably a Greek original, the statue has until now been unanimously dated to the fourth century B.c., but the quiet yet non-classical features of the rounded face, the pensive expression, the elaborate costume, the clear differentiation in texture of the various garments-especially the rendering of the chitonthe impressionistic effect of the fluttering veil, seem to be more in keeping with a date early in the third century B.C. ${ }^{25}$

22 G. A. Mansuelli, Galleria degli Uffizi, Le Sculture I (Rome 1958) no. 36 , pp. 6r-62, fig. 39.

23 Even more remote is the comparison with other standing types vaguely related to the Uffizi Demeter, and often used in Roman times as stock bodies for portrait heads. Cf., e.g., the statue of Livia in the Vatican, Sala dei Busti, W. Amelung, Vatikan Katalog II, pp. 538ff, no. 352 pl. 70; K. F. W. Helbig, Führer durch die öffentlichen Sammlungen klassischer Altertümer in Rom (4th rev. ed., Rome 1963) no. 183, pp. I34-135. See also D. Mustilli, Il Museo Mussolini (Rome 1939) p. 95 no. 18 , pl. $52 \mathrm{c}$.

24 The Pergamene statue mentioned supra (see n. 2r) is over lifesize, and bronze, because of its nature, was so often reused in antiquity that no meaningful conclusions can be drawn from statistical studies on the incidence of bronze statues. Extant bronze monuments do not reflect contemporary practices but merely the hazards of chance.

It has recently been suggested that the Lady from the Sea might be an early Hellenistic representation of a seated Tragedy, and that a fragmentary bronze leg with high-soled sandal in an English private collection might belong to it. See W. Fuchs, "Zur Rekonstruktion einer weiblichen Sitzstatue in Chalkis," JbBerlMuseen 8 (1966) 48 note 24 .

25 Prof. R. Carpenter is of the same opinion and has kindly allowed me to mention it, as expressed in an oral communication. 
We come now to the most interesting aspect of the Izmir bronze: the casting technique. Seldom do we have the opportunity to look inside a metal statue, and examination of the outside can often be misleading, as clearly demonstrated in this particular case. The statue seems to have been made out of a great number of separate pieces, cast independently and then joined by soldering. I have included drawings of the head and neck, and of the entire statue, to facilitate understanding of my description. ${ }^{26}$

The upper part of the head is lost, but enough is preserved to show that the top of the veil virtually constituted the cranium (pl. Ioo, fig. I2). This head covering, as preserved, was cast in three pieces: the two lateral flaps which join the main "crown" at the temples" (pl. 99, fig. 8) and over the nape $;^{28}$ and the rounded part which once formed the dome of the head before descending to the neck, where it is interrupted by the "collar" to be described below. This technical procedure facilitated the windblown effect of the veil flaps; that they were indeed meant to appear in motion, and that their position is not caused by the later vicissitudes of the statue, seems supported by the fact that at no point, as far as preserved, do they join or touch the other garments. See especially pl. roo, fig. ro, where the infiltration of light clearly proves the separation between torso and veil.

The head is actually hardly more than a facemask with two projecting "tongues" arching toward the back, where they are united by the intervening stretch of veil (pl. 99, fig. 6). The face was completed up to slightly above the hairline, and the hair must have been engraved before head and veil were assembled-see over the temples, pl. 99, fig. 9. It is now impossible to determine whether the figure wore a diadem under the veil, but it seems unlikely. At the base of the face, where the chin line joins the throat, runs a "collar," $2.95 \mathrm{~cm}$. in height, which attaches the head to the neck and the neck to the shoulders. This circular strip of metal is perfectly uniform and

\footnotetext{
26 For these drawings I wish to thank Mr. Richard De Puma, of Bryn Mawr College, who devoted to them much of his time and skill. The drawings should be read as follows: the accentuated lines indicate actual joints; the dashed lines represent joints hidden from view. The dotted lines (only in pl. 100, fig. 13) locate patches closing pouring channel-holes with all possible accuracy under the circumstances. Some patches might have escaped detection.

27 The joint is effected by means of nails, or with the tongue-and-groove system. Examples of this latter method
}

functions as a ring, inserted perhaps to adjust the tilting of the head. It does not follow the outline of the jaw, as would seem logical, but runs slightly below it at an ever-widening angle, as can be seen in pl. 100, fig. 13. The joints are visible only from the interior (pl. 99, figs. 7 and 8; contrast fig. 9).

Since the back of the figure is almost totally lost the description must be confined to the front, but there is no doubt that the veil continued down the shoulders as one more separate piece. Over the front, the base of the neck expands into the triangular area of the chest, which is however much larger than it appears on the exterior. Notice for instance the hole visible from the interior along the right edge and toward the apex of the triangle (pl. 99, fig. 8): this hole does not appear on the exterior, where it is covered by a superimposed piece (pl. 98, fig. 3). The soldering line of this large chest triangle is visible from the interior, and even some excess metal resulting from the soldering (pl. 99, figs. 8 and 7).$^{29}$ It should however be admitted that joints are not always easy to detect, even from within, because of good workmanship and the present condition of the bronze.

From the outside, between the edge of the peplos and the chest piece, was inserted the crinkly sliver of the chiton, which is held in place by its position and is not traceable from the interior. But also the heavier folds of peplos and himation do not correspond exactly to the inner surface. Only one major pleat is easily detectable because of the large hole between the breasts visible both from the inside and the outside. From the interior one can also recognize the group of smaller folds below the left breast (pl. 99, fig. 7). But the other exterior folds are cast hollow and then applied independently: namely, in the mantle, I) the short, triangular pleat, with its apex pointing toward the right breast, but disappearing before reaching it, as if tucked under the mantle roll (pl. 98, figs. 3 and $4)$; 2) the heavy fold with many subdivisions, immediately below the above-mentioned pleat, crossing diagonally under the right breast and

from the Hellenistic period already exist. See, e.g., the socalled Philosopher from Anticythera, N. Svoronos, Das Athener National Museum (Athens 1908) 3I n. I, and pl. 4 (arm attachment).

${ }^{28}$ Here the joint is effected along a straight vertical line on either side of the central panel.

29 The practice of inserting a separately made bust on a draped torso is, of course, well known from marble statuary. Cf., e.g., the Demeter of Knidos. 
fusing with the whole over the right side (pl. 98, figs. 2 and 5; pl. Ioo, fig. II); in the peplos, the long vertical pleat descending from the clasp on the right shoulder and bypassing the breast ( $\mathrm{pl}$. 98, figs. 2-5). Probably the left side also preserves a similar joint, but one examination with the naked eye could not determine it with certainty.

One more joint exists, however, and a most unexpected one. Completely invisible from the outside, it runs through the center of the right breast, dividing the figure horizontally into two sections. The line of the joint can be clearly seen in pl. 99, fig. 7 , and it can be partially followed across to the left breast. On the outside most of the joint is hidden under the added folds.

As final technical comments one may mention the inserted eyes, now lost, the lips probably added in copper (as suggested by the fine grooves along the mouth's outline) and a certain amount of cold work, specifically in the hair. One regular hole is visible from the outside at the base of the throat (pl. 99, fig. 6) and served presumably for a pouring channel; a series of patches filling similar rectangular holes can be detected from the interior and give some idea of how the bronze was poured (pl. 99, figs. 7 and 8 and pl. roo, fig. I3). A few mends occur, especially on the neck, some with their filling gone (pl. I0o, fig. Io). Several gashes, again notably on the neck (pls. 98 and 99, figs. 2 and 6) suggest vandalism, or perhaps an attempt to break up the statue, presumably in antiquity (pl. 99, fig. 6).

It is unlikely that all these details of manufacture would have been noticed had the statue been preserved in its entirety, or at least with its back in place. The technique raises various questions as to the making of an original model; the sectioning of the model into parts, or perhaps the section-

\footnotetext{
30 I am greatly indebted to Prof. Bernard Goldman of Wayne State University for many illuminating comments on bronze casting. He pointed out to me that for the single casting of a statue of this size a very large foundry process would indeed be needed to preheat the mold, to melt all the bronze needed at one time and to pour. Following the "piece method" instead, only several small runs of bronze would be required. Moreover, hollow casting necessitates many sprues and vents and the difficult ramming of the core; piece casting can virtually be considered solid casting, thus eliminating the use of involved cores and sprues. Finally, the subsequent trimming and reassembling, by soldering, sweating and welding the joints, is a process known from much earlier times and clearly illustrated in the so-called Foundry Cup, lately discussed by $\mathrm{H}$. Thompson in Essays in Memory of K. Lehmann, Marsyas Supplement I, ed. L. F. Sandler (New York 1964)
}

ing of the mold alone; the problem of the unity of the work of art (was the reassembling of the pieces a purely mechanical task to be performed by workshop technicians, or did it involve the original artist?); the extent and importance of the casting factories. Obviously casting in so many pieces required less extensive installations, eliminated the problem of removing a central core, and even reduced the risks of flaws and imperfections in the casting; if a section of the statue resulted faulty, that alone would have had to be recast, and not the entire monument. ${ }^{30}$

Unfortunately our knowledge of bronze casting is still limited, even after the extensive publications by Kluge and Lehmann-Hartleben, and the more recent studies of D. L. Haynes, J. Charbonneaux, E. Caley and others. ${ }^{31} \mathrm{We}$ still tend to visualize ancient bronze figures as basically cast in one piece, at most with only arms, legs and head cast separately for ease in pouring. ${ }^{32} \mathrm{~A}$ most pertinent enquiry into the making of a specific bronze statue has already provided different evidence. ${ }^{33}$ With the aid of a diminutive camera introduced into the statue through a hole, T. Dohrn was able to photograph the interior of a late Etruscan bronze, the "Arringatore," and to record all the inner joints and lines of soldering which were hard to detect on the outside. It was thus discovered that the figure had been cast in several pieces: not only the head, arms and legs, but also the upper and lower torso, with a definite break at mid-body. The faint line can now also be seen in the photographs, ${ }^{34}$ running slightly above the large rectangular break in the back and surrounding the body at hip level, to disappear only where covered by the extension of the left forearm, which had been cast separately.

Dohrn compares this procedure with a much

323-328.

31 The standard work is $\mathrm{K}$. Kluge and $\mathrm{K}$. Lehmann-Hartleben, Die antiken Grossbronzen (Berlin 1927); see also K. Kluge, "Die Gestaltung des Erzes in der archaisch-griechischen Kunst," JdI 44 (I929) I-30. For D. E. L. Haynes' comments see $A A$ 1962, cols. 803-807, and RömMitt 67 (1960) 45-47. J. Charbonneaux, Les Bronzes Grecs (Paris 1958). E. R. Caley, Analysis of Ancient Metals (New York 1964). See also A. J. B. Wace, "The Chatsworth Head," JHS 58 (I938) 90-95.

$32 \mathrm{Cf}$. the mold for an archaic kouros, admittedly under lifesize, found in the Athenian Agora, Hesperia 6 (1937) 82, which certainly seems to suggest one-piece casting.

33 T. Dohrn, "L'Arringatore, capolavoro del Museo Archeologico di Firenze," $B d A 2$ (1964) 97-114, and $A A$ 1965, cols. I 23-I 42 .

34 Dohrn, op.cit. (supra, n. 33) 98-99, figs. I-2. 
earlier Greek practice exemplified by the Delphi Charioteer, ${ }^{35}$ where upper and lower torso are also separate and join at the waist under the protecting cover of the belt. However the Charioteer's sculptor chose a much more natural and plausible location for a joint, while the selection of the Arringatore's master seems rather arbitrary. ${ }^{36}$ Therefore Dohrn wonders what process was followed by fourth century or Hellenistic bronze casters for their many draped honorary statues. The "Lady from the Sea" supplies a partial answer, but certainly a much more complex answer than the Arringatore would have led us to expect. The in-

35 F. Chamoux, L'Aurige de Delphes, Fouilles de Delphes IV:5 (Paris 1955). Cf. a $\rightarrow$ R. Hampe's review, Gnomon 32 (1960) 60-73.

36 "Sembra perciò che il bronzista che fuse la statua dell' creased skill of marble and bronze workers in the Hellenistic and subsequently in the Roman periods has prepared us to look for always greater achievements and even for complete one-piece castings. We may perhaps have to realize that the artists' unquestionable ability lay not in the elimination but in the perfect dissimulation of the joints. It is therefore to be hoped that more bronze statues can be examined at close quarters, from the interior, to give us a better knowledge of bronze casting in antiquity.

\section{BRYN MAWR COLLEGE}

'Arringatore' abbia adottato il processo già precedentemente usato in Grecia, senza adeguarlo al suo compito particolare." Dohrn, op.cit. (supra, n. 33) I03. 


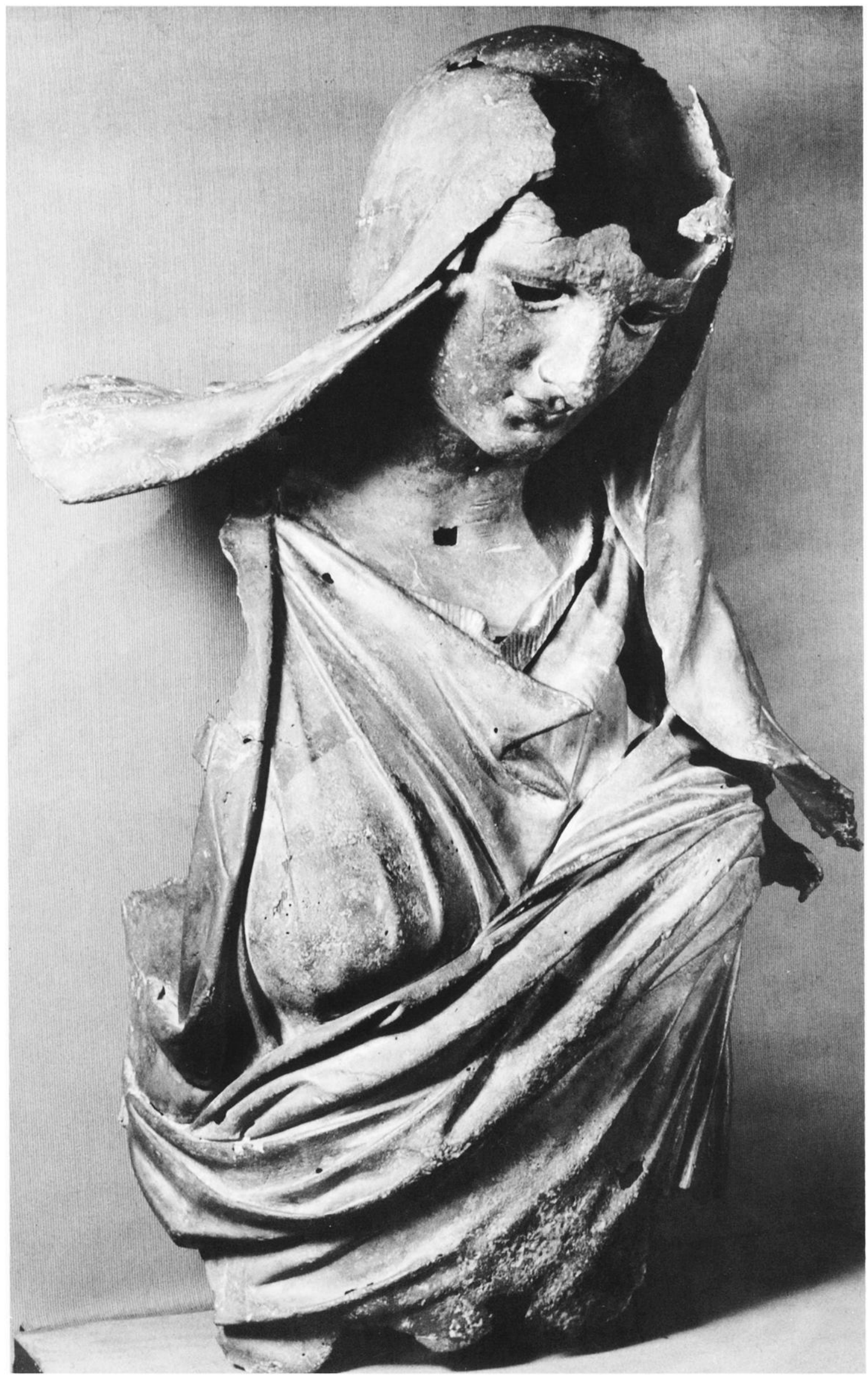

Fig. I. Courtesy University Museum, Philadelphia 
P L A TE 98 R IDGW A Y

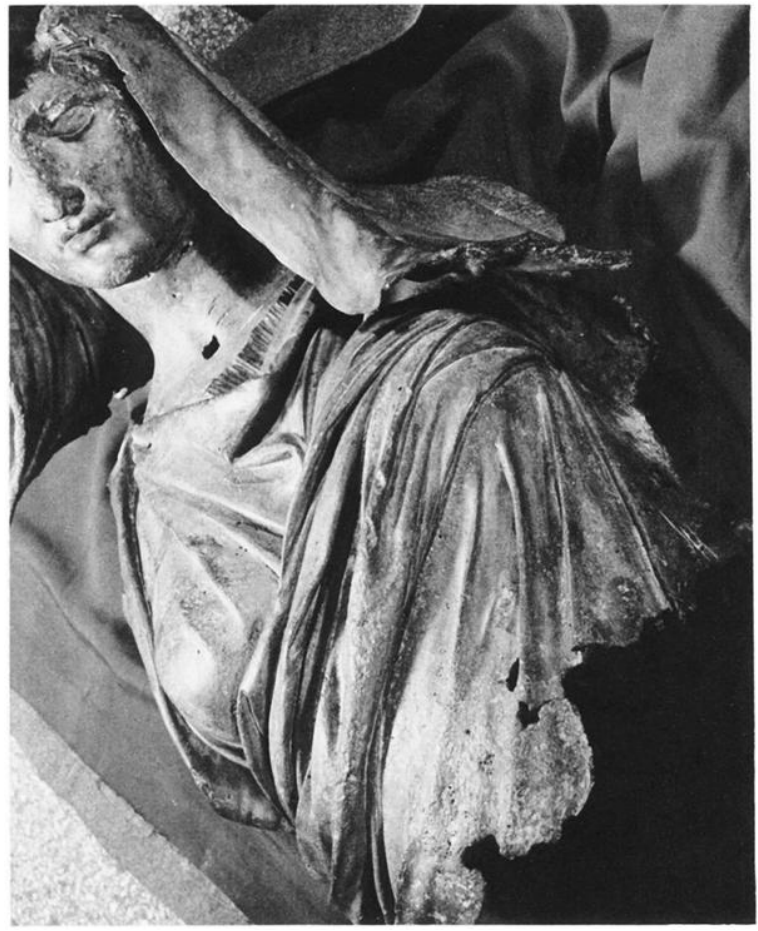

Fig. 2

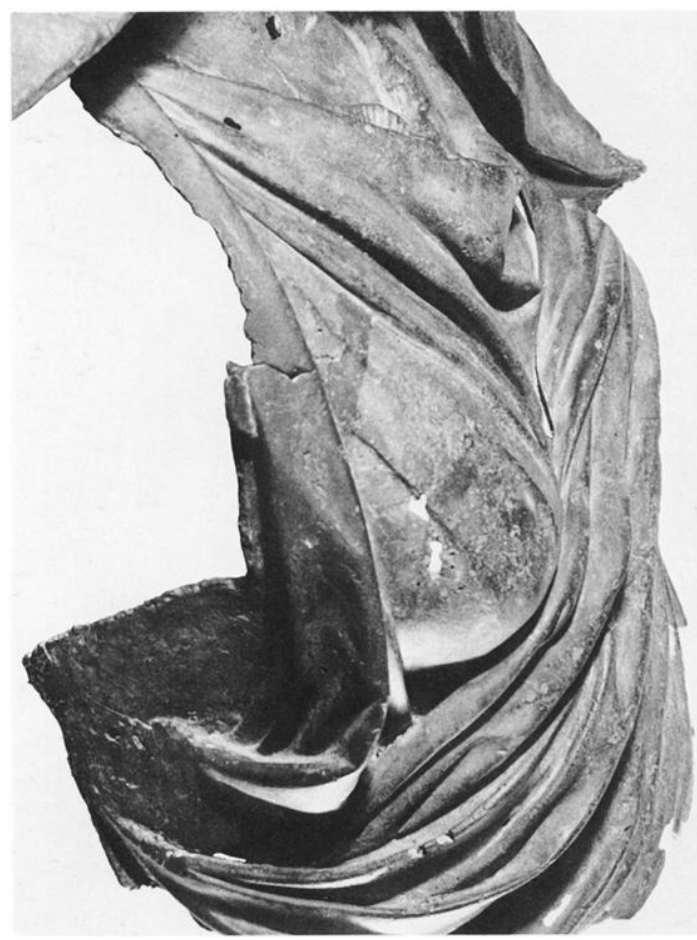

Fig. 4

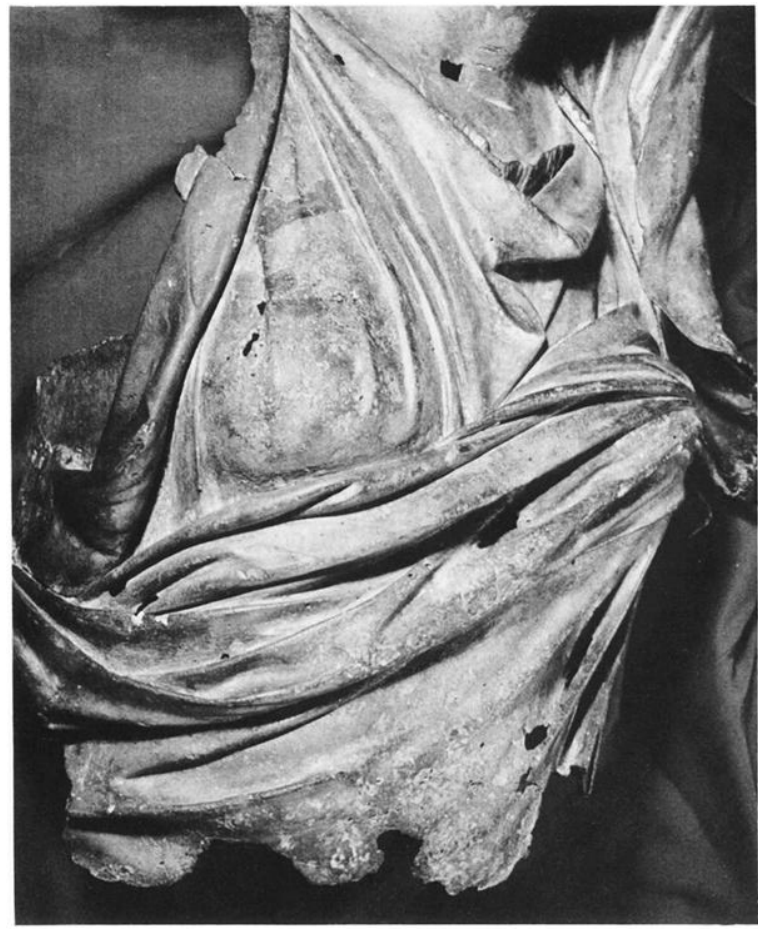

Fig. 3

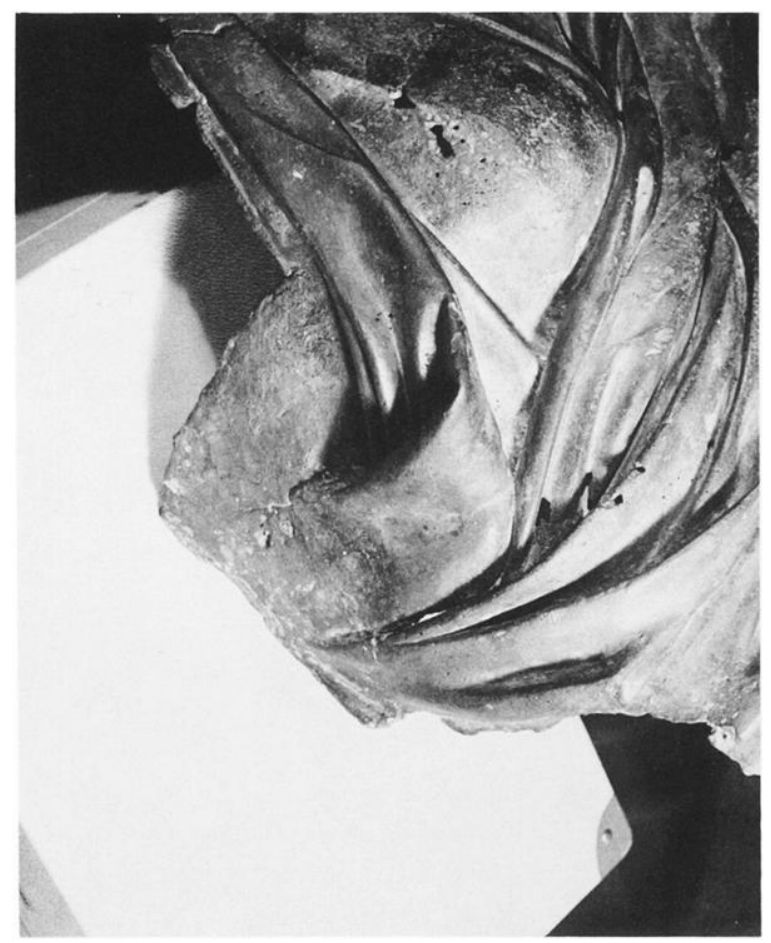

Fig. 5 


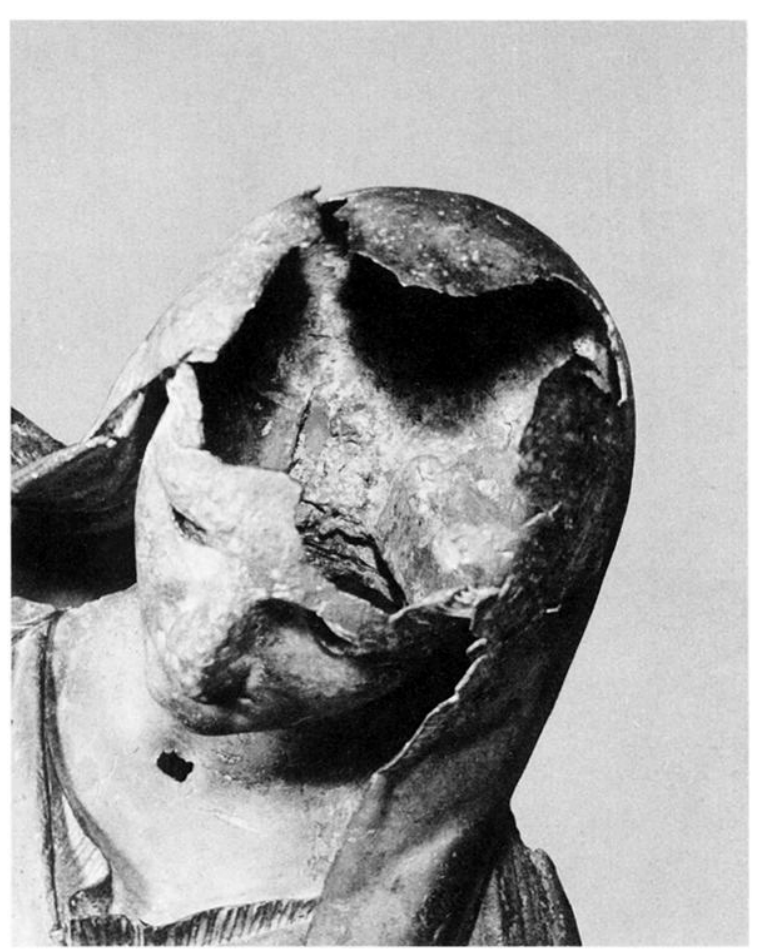

Fig. 6

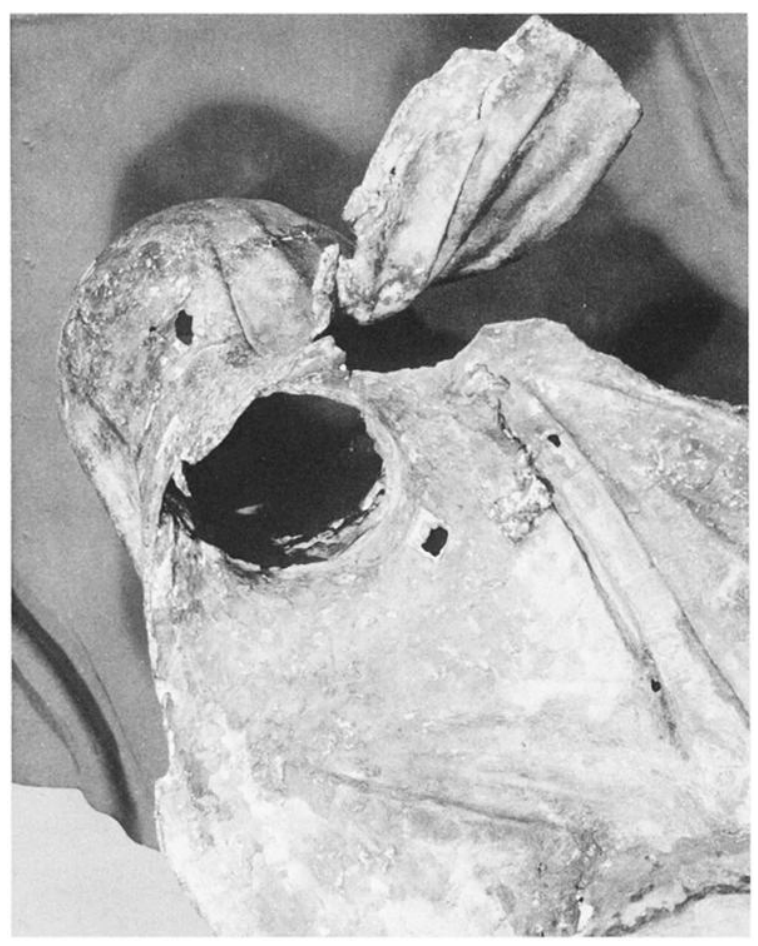

Fig. 8

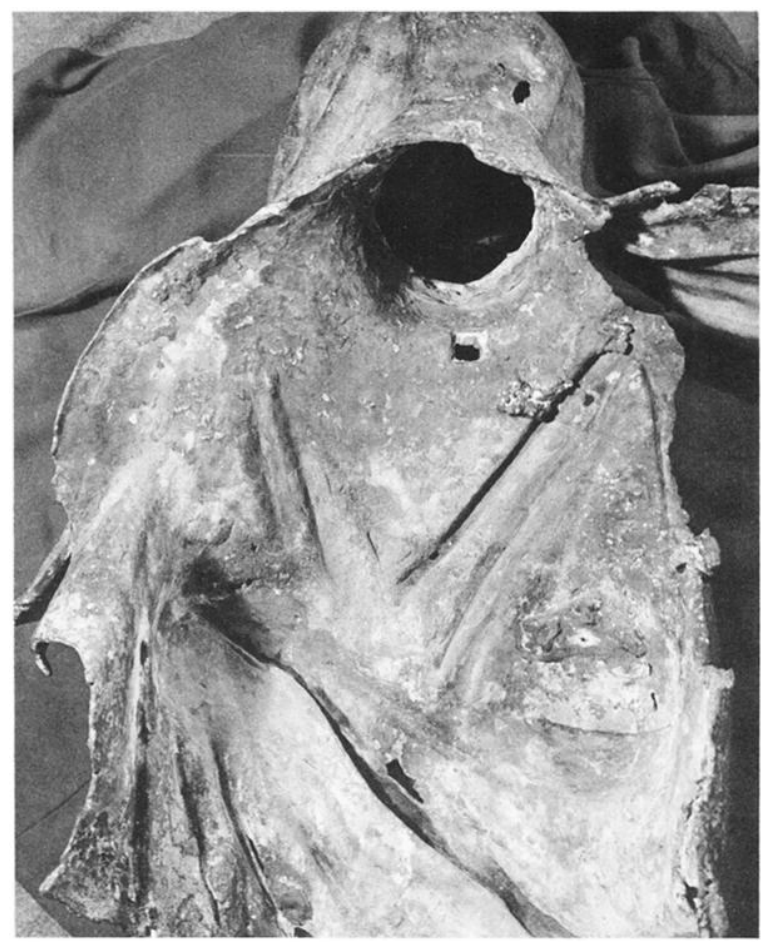

Fig. 7

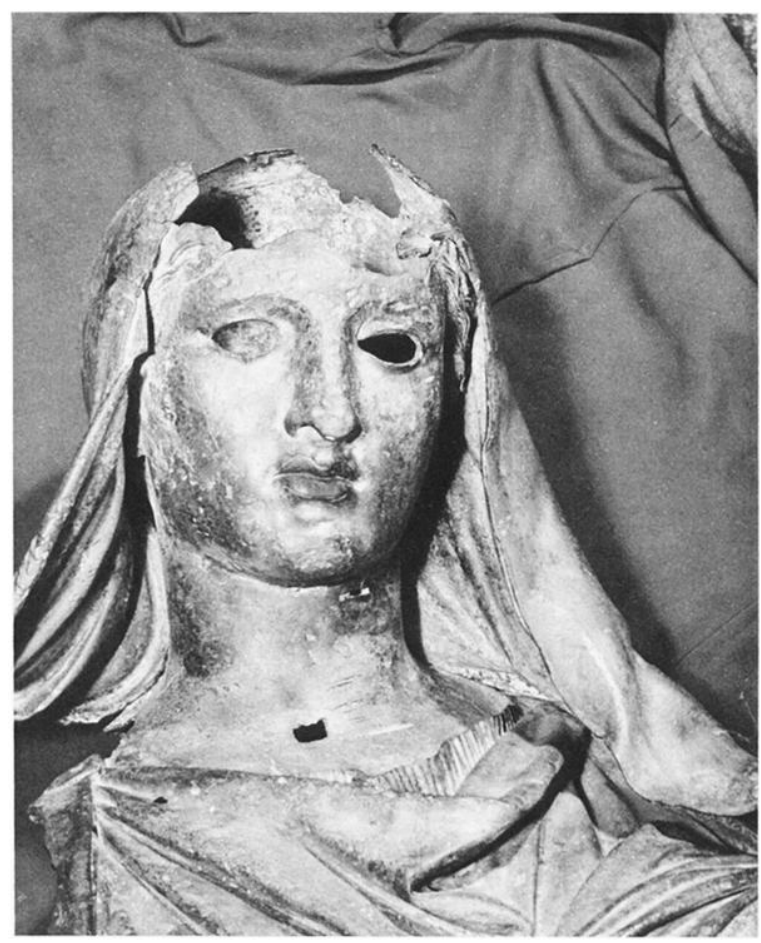

Fig. 9 
PLATE IOO RIDG W Y

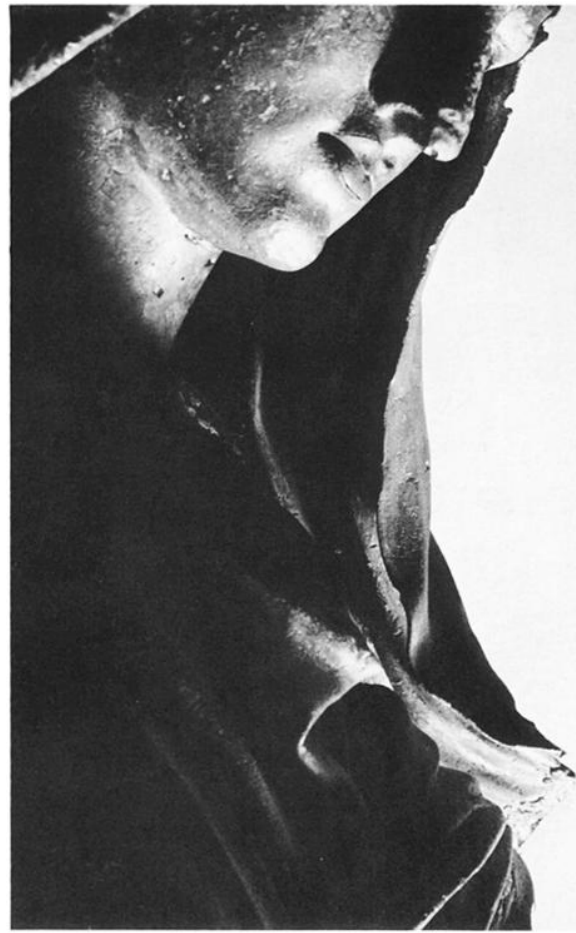

Fig. Io

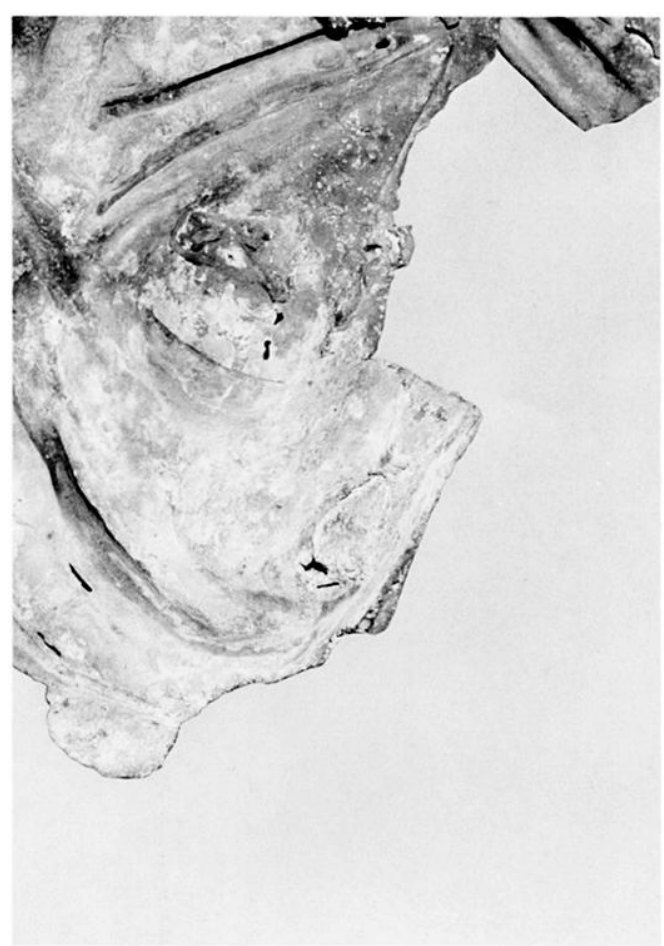

Fig. II

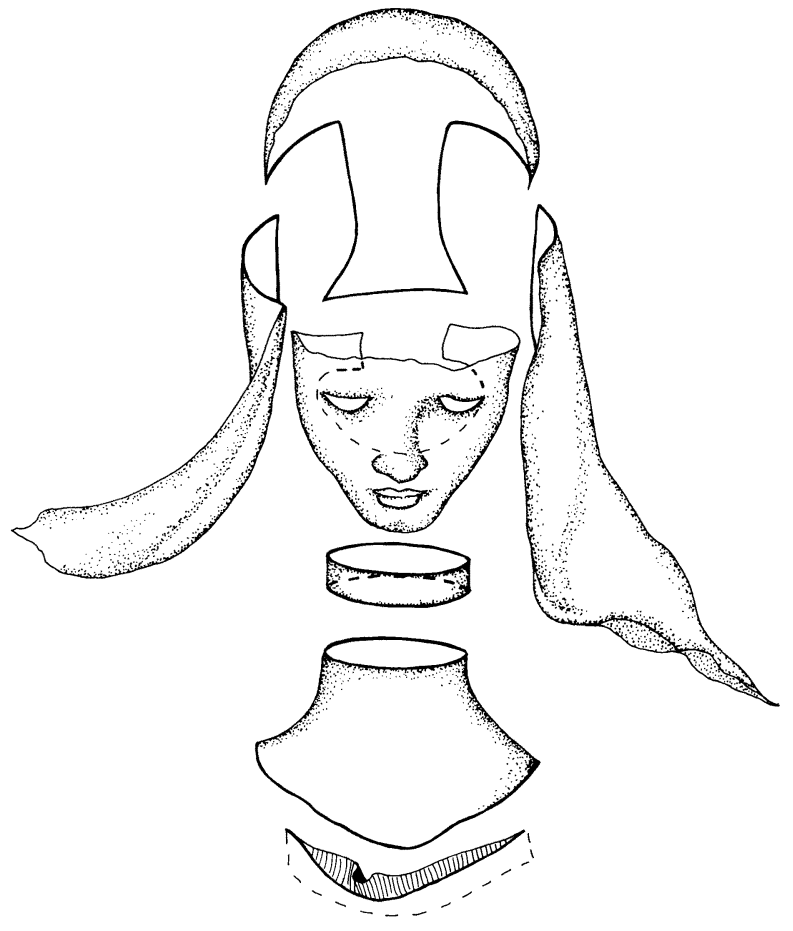

Fig. 12

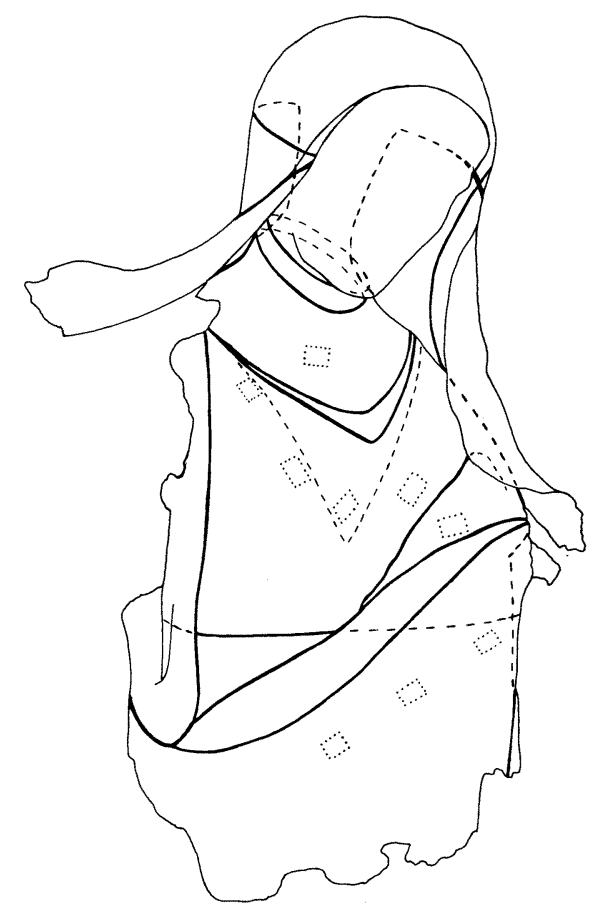

Fig. 13 